\title{
Evaluating Bispyribac-sodium and Sulfosulfuron for Control of Roughstalk Bluegrass
}

\author{
Debbie Morton $^{1,7}$, Daniel Weisenberger ${ }^{2}$, and Zachary Reicher ${ }^{3}$ \\ Department of Agronomy, Purdue University, 915 W. State Street, West \\ Lafayette, IN 47907-2054
}

Bruce Branham $^{4}$ and Bill Sharp
Natural Resources and Environmental Science, W-421 Turner Hall, $1102 \mathrm{~S}$
Goodwin, Urbana, IL 61801

Roch Gaussoin ${ }^{3}$

Department of Agronomy \& Horticulture, University of Nebraska, 362 Plant Science, Lincoln, NE 68583-0915

\author{
John Stier ${ }^{4}$ and Eric Koeritz ${ }^{6}$ \\ Department of Horticulture, University of Wisconsin-Madison, 1575 Linden \\ Drive, Madison, WI 53715
}

Additional index words. Poa trivialis, certainty, velocity

\begin{abstract}
Roughstalk bluegrass (Poa trivialis L.) is a troublesome weed on golf courses, home lawns, and athletic fields from the Midwest to the mid-Atlantic states. Bispyribacsodium and sulfosulfuron have recently been labeled for roughstalk bluegrass control, but their use needs to be refined. Our objective was to determine the most effective herbicide strategies for control of roughstalk bluegrass. Initial studies were conducted during 2005 in Illinois and Indiana and follow-up studies in 2006 in Indiana, Illinois, South Dakota (partial shade and full sun), and Wisconsin. Applications starting in the warmer temperatures of late May and June 2005 were more effective than those starting in mid-May. Bispyribac-sodium (a.i.) was applied at 74 or $114 \mathrm{~g} \cdot \mathrm{ha}^{-1}$ four times at 2-week intervals decreased roughstalk bluegrass cover to $1 \%$ and $0 \% 12$ weeks after initial treatment (WAIT) in Illinois and Indiana in 2005, respectively, whereas sulfosulfuron (a.i.) at 13 or $27 \mathrm{~g} \cdot \mathrm{ha}^{-1}$ applied twice at 2 -week intervals decreased cover to no less than $18 \%$. In 2006, bispyribac-sodium was most effective in Indiana and Illinois decreasing cover to as low as $4 \%$, whereas sulfosulfuron was most effective in South Dakota resulting in a decrease in cover to as low as $7 \%$, and both herbicides performed similarly in Wisconsin. Three applications of sulfosulfuron (a.i.) at $27 \mathrm{~g} \cdot \mathrm{ha}^{-1}$ at 2 -week intervals or four applications of bispyribac-sodium (a.i.) at 56 or $74 \mathrm{~g} \cdot \mathrm{ha}^{-1}$ at 2-week intervals were most effective for roughstalk bluegrass control.
\end{abstract}

Roughstalk bluegrass is a troublesome weed on golf courses, home lawns, and athletic fields from the Midwest to the midAtlantic states. Roughstalk bluegrass has poor drought and heat tolerance, poor to fair wear tolerance, and is susceptible to a number of diseases, including dollar spot (Christians, 2004). Thus, turf areas with substantial roughstalk bluegrass populations thin in late

Received for publication 10 May 2007. Accepted for publication 1 July 2007.

Purdue Agriculture Research Program Journal Number 2007-18122.

${ }^{1}$ Graduate Research Assistant.

${ }^{2}$ Research Agronomist.

${ }^{3}$ Professor.

${ }^{4}$ Associate Professor.

${ }^{5}$ Research Specialist.

${ }^{6}$ Turfgrass Research Specialist.

${ }^{7}$ To whom reprint requests should be addressed; e-mail demorton@purdue.edu.
(Poa annua L.) and roughstalk bluegrass in creeping bentgrass (Agrostis stolonifera L.) and perennial ryegrass (Lolium perenne L.) golf course fairways or sod farms (Anonymous, 2004). Bispyribac-sodium is an acetolactate synthase-inhibiting herbicide and belongs to the pyrimidinyl carboxy herbicide family (Shimizu et al., 2002). Efficacy of bispyribac-sodium appears to be temperature-related because annual bluegrass has greater sensitivity to bispyribac-sodium at warmer temperatures $\left(20\right.$ to $\left.30{ }^{\circ} \mathrm{C}\right)$ than at cooler temperatures $\left(10{ }^{\circ} \mathrm{C}\right)(\mathrm{McC}$ cullough and Hart, 2006a)

Sulfosulfuron is currently sold under the trade name Certainty (Monsanto, St. Louis). Sulfosulfuron is labeled to control roughstalk bluegrass in creeping bentgrass tees and fairways (Anonymous, 2005). However, tolerance of other cool-season turfgrass species to sulfosulfuron is not well understood (Lycan and Hart, 2004). The objective of this experiment was to determine the most effective selective herbicide strategies for control of roughstalk bluegrass.

\section{Materials and Methods}

2005. Treatments in the initial studies began in May and June in Urbana, IL, and West Lafayette, IN. Specific details for each site are listed in Table 1. Treatments were arranged in a $2 \times 2 \times 2$ factorial, including two initial application dates (mid to late May and mid to late June), two herbicides (bispyribac-sodium and sulfosulfuron), and two rates (high and low). Herbicide treatments were sulfosulfuron (a.i.) at 13 or $27 \mathrm{~g} \cdot \mathrm{ha}^{-1}$ applied twice at 2-week intervals and bispyribac-sodium (a.i.) at 74 or $114 \mathrm{~g} \cdot \mathrm{ha}^{-1}$ applied four times at 2-week intervals. An untreated control was also included. All sulfosulfuron treatments included MON 0818 surfactant at $0.25 \% \mathrm{v} / \mathrm{v}$.

2006. Treatments were initiated in June in five locations, including West Lafayette, IN; Urbana, IL; Dakota Dunes, SD (partial shade and full sun); and Verona, WI. Specific details for each site are listed in Table 2. Treatments were arranged in a randomized complete block design with three replications. Four sulfosulfuron treatments, three bispyribac-sodium treatments, and an untreated control were included at each location. Sulfosulfuron (a.i.) treatments were applied either two or three times at 2-week intervals at 13 or $27 \mathrm{~g} \cdot \mathrm{ha}^{-1}$. Bispyribacsodium (a.i.) treatments were applied four times at 2 -week intervals at 37,56 , or 74 $\mathrm{g} \cdot \mathrm{ha}^{-1}$. All sulfosulfuron treatments included MON 0818 surfactant at $0.25 \% \mathrm{v} / \mathrm{v}$.

In both years and at all locations, roughstalk bluegrass cover was rated visually as a percentage of cover in each plot. Phytotoxicity was also rated every other week on a scale of 1 to 9 in which $1=$ brown, $7=$ acceptable, and $9=$ no phytotoxicity. Error variances were not homogenous among locations within years and therefore data for each location were analyzed and presented separately. All data were analyzed using PROC 
ANOVA from SAS (version 9.1; SAS Institute, Cary, NC) and separated with Tukey's least significant difference at $P \leq 0.05$.

\section{Results and Discussion}

2005 Illinois. When averaged over both herbicide treatments and application rates, May applications decreased roughstalk bluegrass cover to $19 \%$ at 8 weeks after initial treatment (WAIT) compared with $73 \%$ in untreated plots, and June applications decreased cover to only $34 \%$ compared with $73 \%$ in untreated plots (Table 3 ). These data may be somewhat misleading because May treatments received a second application 6 weeks before the 8 WAIT rating, whereas June treatments received their second application only 2 weeks before the 8 WAIT rating. Both May and June treatments received their second applications at least 6 weeks before the 12 WAIT rating, and thus May and June applications provided equivalent control at 12 WAIT.

Bispyribac-sodium was more effective than sulfosulfuron at this site. Averaged over all application dates and rates, bispyribacsodium decreased cover to $6 \%$ and $1 \%$ at 8 and 12 WAIT, respectively, whereas sulfosulfuron decreased cover to $46 \%$ and $32 \%$ at 8 and 12 WAIT, respectively (Table 3). By 12 WAIT, the rate of bispyribac-sodium had no effect on rough bluegrass cover, but the high rate of sulfosulfuron decreased rough bluegrass cover twice as much as the low rate (Table 3).

At 8 WAIT, there was a date $x$ rate $\times$ herbicide interaction in percent cover of

Table 1. Site information for experimental location in Illinois and Indiana in 2005.

\begin{tabular}{|c|c|c|}
\hline & Illinois & Indiana \\
\hline Roughstalk bluegrass variety & Unknown & Laser \\
\hline Mowing height $(\mathrm{cm})$ & 1.27 & 1.27 \\
\hline Mowing frequency (times/week) & 2 & 3 \\
\hline Irrigation & To prevent stress & To prevent stress \\
\hline Soil texture & Silt clay loam & Silt loam \\
\hline Soil pH & 6.6 & 7.2 \\
\hline Soil $\mathrm{mg} \cdot \mathrm{kg}^{-1} \mathrm{P}$ & 30 & 79 \\
\hline Soil $\mathrm{mg} \cdot \mathrm{kg}^{-1} \mathrm{~K}$ & 300 & 169 \\
\hline Percent soil organic matter & $3.5 \%$ & $3.8 \%$ \\
\hline Annual $\mathrm{N} \mathrm{kg} \cdot \mathrm{ha}^{-1} \cdot \mathrm{yr}^{-1}$ & 147 & 196 \\
\hline Spray volume $\left(\mathrm{L} \cdot \mathrm{ha}^{-1}\right)$ & 489 & 814 \\
\hline Spray pressure $(\mathrm{kPa})$ & 221 & 207 \\
\hline Nozzle size & 8002 & 8002 \\
\hline \multicolumn{3}{|l|}{ Initial application dates } \\
\hline May applications & 27 th & 16 th \\
\hline June applications & 27 th & 13 th \\
\hline \multicolumn{3}{|l|}{ Daily high/low temperatures ${ }^{\mathrm{z}}\left({ }^{\circ} \mathrm{C}\right)$} \\
\hline Initial May application & $24 / 1$ & $14 / 4$ \\
\hline Second May application & $33 / 21$ & $26 / 13$ \\
\hline Third May application & $34 / 22$ & $24 / 19$ \\
\hline Fourth May application & $31 / 18$ & $35 / 19$ \\
\hline Initial June application & $34 / 22$ & $24 / 19$ \\
\hline Second June application & $29 / 19$ & $35 / 19$ \\
\hline Third June application & $26 / 13$ & $32 / 15$ \\
\hline Fourth June application & $36 / 22$ & $34 / 22$ \\
\hline
\end{tabular}

${ }^{\mathrm{z}}$ All temperatures are for the day of the application indicated.

roughstalk bluegrass (Table 3 ). This was the result of consistent and effective control from bispyribac-sodium regardless of application date or rate, but sulfosulfuron provided an inconsistent response. Regardless of application date or rate, bispyribac-sodium reduced cover to $13 \%$ or less at 8 WAIT, but sulfosulfuron reduced roughstalk bluegrass cover to between $42 \%$ and $63 \%$ compared with $73 \%$ cover in the untreated control (data not shown).

2005 Indiana. Averaged over herbicides and rates, June applications were more effective than May applications at 12 WAIT (Table 3). This was primarily the result of poor control from May sulfosulfuron applications, which produced $32 \%$ cover compared with $4 \%$ cover from June applications and $28 \%$ cover in the untreated plots (Table 3 ). This difference in control is likely because efficacy of sulfosulfuron increases as temperature increases. Absorption of sulfosulfuron increases in downy brome (Bromus tectorum L.), wild oat (Avena fatua L.), and jointed goatgrass (Aegilops cylindrica Host.) as day/night temperatures increase from $5 / 3{ }^{\circ} \mathrm{C}$ to $25 / 23{ }^{\circ} \mathrm{C}$, which resulted in better control of those grasses (Olson et al., 2000). McCullough and Hart (2006b) also have early data suggesting increased sensitivity to sulfosulfuron in roughstalk bluegrass at higher temperatures. In our study, high temperatures on the initial application date in May were $10^{\circ} \mathrm{C}$ less than high temperatures on the initial application date in June.

Temperature could also explain the poor control from May sulfosulfuron in Indiana and the effective control from the same application in Illinois. Because of weather delays, initial spray dates in Illinois were 2 weeks later than Indiana's initial spray dates. The day/night temperatures on the day of initial May applications were $24 / 12{ }^{\circ} \mathrm{C}$ in Illinois and $14 / 4{ }^{\circ} \mathrm{C}$ in Indiana, whereas temperatures on the initial June applications were greater than $23{ }^{\circ} \mathrm{C}$ in both states. This $10^{\circ} \mathrm{C}$ difference in temperature on the initial

Table 2. Site information for experimental locations in Indiana, Illinois, South Dakota, and Wisconsin in 2006.

\begin{tabular}{|c|c|c|c|c|c|}
\hline & Indiana & Illinois & South Dakota-sun & South Dakota-shade & Wisconsin \\
\hline Roughstalk bluegrass variety & Laser & Unknown & Unknown & Unknown & Unknown \\
\hline Mowing height $(\mathrm{cm})$ & 1.27 & 6.4 & 1.27 & 1.27 & 1.13 \\
\hline Mowing frequency (times/week) & 3 & 2 & 3 & 3 & $3-4$ \\
\hline Irrigation & To prevent stress & To prevent stress & To prevent stress & To prevent stress & To prevent stress \\
\hline Soil texture & Silt loam & Silty clay loam & Silty loam & Silty loam & Silty clay \\
\hline Soil pH & 7.2 & 6.6 & 8.2 & 8.2 & 7.1 \\
\hline Soil $\mathrm{mg} \cdot \mathrm{kg}^{-1} \mathrm{P}$ & 79 & 30 & 18 & 18 & 99 \\
\hline Soil $\mathrm{mg} \cdot \mathrm{kg}^{-1} \mathrm{~K}$ & 169 & 300 & 37 & 37 & 182 \\
\hline Percent soil organic matter & $3.8 \%$ & $3.5 \%$ & $3.0 \%$ & $3.0 \%$ & $4.1 \%$ \\
\hline Annual $\mathrm{N} \mathrm{kg} \cdot \mathrm{ha}^{-1} \mathrm{yr}^{-1}$ & 196 & 147 & 123 & 123 & 73 \\
\hline Spray volume $\left(\mathrm{L} \cdot \mathrm{ha}^{-1}\right)$ & 814 & 489 & 814 & 814 & 814 \\
\hline Spray pressure $(\mathrm{kPa})$ & 207 & 221 & 276 & 276 & 290 \\
\hline Nozzle size & 8002 & 8002 & 8002 & 8002 & 8004 \\
\hline Initial application date & 15 June & 23 June & 26 June & 26 June & 19 June \\
\hline \multicolumn{6}{|l|}{ Daily high/low temperatures ${ }^{\mathrm{z}}\left({ }^{\circ} \mathrm{C}\right)$} \\
\hline Initial May application & $27 / 16$ & $30 / 18$ & $28 / 13$ & NA & $22 / 12$ \\
\hline Second May application & $28 / 1$ & $27 / 14$ & $29 / 19$ & NA & $25 / 14$ \\
\hline Third May application & $28 / 21$ & $27 / 17$ & $34 / 23$ & NA & $26 / 11$ \\
\hline Fourth May application & $28 / 22$ & $31 / 18$ & $28 / 17$ & NA & $33 / 23$ \\
\hline
\end{tabular}

${ }^{\mathrm{z}} \mathrm{All}$ temperatures are for the day of the application indicated.

$\mathrm{NA}=$ Not available. 
May spray dates could have been enough to decrease the efficacy of sulfosulfuron in Indiana (McCullough and Hart, 2006b).

Bispyribac-sodium efficacy also increases with temperature, and the threshold for effective control of Poa annua is $\approx 21{ }^{\circ} \mathrm{C}$ (Lycan and Hart, 2006). However, we saw no differences in control of roughstalk bluegrass between May and June bispyribac-sodium applications in Indiana although temperatures increased dramatically after the initial May application date. Initial application date day/night temperatures were $14 / 4{ }^{\circ} \mathrm{C}$, whereas day/night temperatures on ensuing application dates were $24 / 13{ }^{\circ} \mathrm{C}$ or greater. Thus, only one of the four applications of May bispyribac-sodium treatments would have been affected. Conversely, one of the two May sulfosulfuron applications was made in low temperatures, which likely reduced efficacy.

The low rate of sulfosulfuron decreased cover to only $24 \%$ compared with $11 \%$ cover resulting from the high-rate 12 WAIT (Table 3). There was no difference in effect of the rate of bispyribac-sodium because both rates reduced rough bluegrass cover to $0 \%$ compared with $28 \%$ in the control plots 12 WAIT (Table 3).

Almost all sulfosulfuron and bispyribacsodium treatments caused minor phytotoxicity regardless of location, rate, or application date (data not shown). However, phytotoxicity was temporary (2 weeks) and within acceptable levels for golf fairway turf. Bispyribac-sodium (a.i.) applied at $114 \mathrm{~g} \cdot \mathrm{ha}^{-1}$ resulted in the most chlorosis, but this rate is above the current labeled rates. Because no differences in control resulted from the two rates of bispyribac-sodium, the $113 \mathrm{~g} \cdot \mathrm{ha}^{-1}$ rate was dropped from the 2006 trials. Furthermore, because herbicides were more effective when applied in June, all treatments were initiated in June 2006.

2006 Indiana. There were no agronomically significant differences in cover at 4 WAIT despite statistically significant differences (Table 4). Sulfosulfuron (a.i.) at 27 $\mathrm{g} \cdot \mathrm{ha}^{-1}$ applied three times and all of the bispyribac-sodium treatments reduced cover to $14 \%$ or less at 8 WAIT compared with $97 \%$ cover in the untreated control. At 12 WAIT, bispyribac-sodium (a.i.) at 56 and $74 \mathrm{~g} \cdot \mathrm{ha}^{-1}$ provided the best control decreasing cover to $12 \%$ and $4 \%$, respectively, compared with 98\% cover in the untreated control. Bispyribac-sodium (a.i.) at $37 \mathrm{~g} \cdot \mathrm{ha}^{-1}$ decreased cover to $37 \%$ at 12 WAIT, which was statistically equivalent to sulfosulfuron applied three times at $27 \mathrm{~g} \cdot \mathrm{ha}^{-1}$. Overall, bispyribac-sodium (a.i.) applied at 56 and $74 \mathrm{~g} \cdot \mathrm{ha}^{-1}$ provided the best control of roughstalk bluegrass in Indiana.

2006 Illinois. Treatments had no effect at 4 WAIT (Table 5). Three applications of sulfosulfuron (a.i.) at $27 \mathrm{~g} \cdot \mathrm{ha}^{-1}$ decreased cover to $14 \%$ at 8 WAIT compared with $97 \%$ in the untreated control. All bispyribacsodium treatments also performed well in Illinois reducing rough bluegrass cover by $91 \%$ or more compared with the untreated

Table 3. Percent cover ${ }^{2}$ of roughstalk bluegrass as influenced by bispyribac-sodium and sulfosulfuron in Illinois and Indiana in 2005.

\begin{tabular}{|c|c|c|c|c|}
\hline & \multicolumn{2}{|c|}{ Illinois } & \multicolumn{2}{|c|}{ Indiana } \\
\hline & 8 WAIT $^{y}$ & $12 \mathrm{WAIT}$ & 8 WAIT & $12 \mathrm{WAIT}$ \\
\hline \multicolumn{5}{|l|}{$\overline{\text { Date }}$} \\
\hline May & $19 \mathrm{a}^{\mathrm{x}}$ & 17 & 46 & $16 \mathrm{~b}$ \\
\hline June & $34 \mathrm{~b}$ & 17 & 49 & $2 \mathrm{a}$ \\
\hline \multicolumn{5}{|l|}{ Herbicide } \\
\hline Bispyribac-sodium & $6 \mathrm{a}$ & $1 \mathrm{a}$ & $25 \mathrm{a}$ & $0 \mathrm{a}$ \\
\hline Sulfosulfuron & $46 \mathrm{~b}$ & $32 \mathrm{~b}$ & $70 \mathrm{~b}$ & $18 \mathrm{~b}$ \\
\hline \multicolumn{5}{|l|}{ Rate $^{\mathrm{w}} \times$ herbicide } \\
\hline Bispyribac-sodium low & 9 & $2 \mathrm{a}$ & 29 & $0 \mathrm{a}$ \\
\hline Sulfosulfuron low & 47 & $43 \mathrm{c}$ & 76 & $24 \mathrm{~b}$ \\
\hline Bispyribac-sodium high & 4 & $1 \mathrm{a}$ & 21 & $0 \mathrm{a}$ \\
\hline Sulfosulfuron high & 45 & $21 \mathrm{~b}$ & 64 & $11 \mathrm{a}$ \\
\hline \multicolumn{5}{|l|}{ Date $\times$ herbicide } \\
\hline Bispyribac-sodium May & $3 \mathrm{a}$ & 1 & $2 \mathrm{a}$ & $0 \mathrm{a}$ \\
\hline Sulfosulfuron May & $35 \mathrm{~b}$ & 32 & $91 \mathrm{c}$ & $32 \mathrm{~b}$ \\
\hline Bispyribac-sodium June & $10 \mathrm{a}$ & 2 & $48 \mathrm{~b}$ & $0 \mathrm{a}$ \\
\hline Sulfosulfuron June & $58 \mathrm{c}$ & 33 & $49 \mathrm{~b}$ & $4 \mathrm{a}$ \\
\hline \multicolumn{5}{|l|}{ Analysis of variance ${ }^{\mathrm{v}}$} \\
\hline Date & ** & NS & NS & ** \\
\hline Herbicide & ** & ** & ** & ** \\
\hline Rate & NS & ** & ** & * \\
\hline Date $\times$ herbicide & * & NS & ** & ** \\
\hline Rate $\times$ date & NS & NS & NS & NS \\
\hline Rate $\times$ herbicide & NS & ** & NS & * \\
\hline Rate $\times$ date $\times$ herbicide & * & NS & NS & NS \\
\hline
\end{tabular}

${ }^{2}$ Percent cover in the untreated control plots was $73 \%$ and $70 \%$ in Illinois 8 and 12 WAIT, respectively, and $94 \%$ and $28 \%$ in Indiana 8 and 12 WAIT, respectively.

${ }^{\mathrm{y}} \mathrm{WAIT}=$ weeks after initial treatment.

${ }^{x}$ Means in a column followed by the same letter are not significantly different at $P \leq 0.05$.

${ }^{w}$ Low and high rates for bispyribac-sodium (a.i.) were 74 and $114 \mathrm{~g} \cdot \mathrm{ha}^{-1}$, respectively, and low and high rates for sulfosulfuron (a.i.) were 13 and $27 \mathrm{~g} \cdot \mathrm{ha}^{-1}$, respectively.

${ }^{\mathrm{NS}}$, * ** Not significant, significant at $P \leq 0.05$, significant at $P \leq 0.01$, respectively.

Table 4. Percent cover of roughstalk bluegrass as influenced by bispyribac-sodium and sulfosulfuron in Indiana in 2006.

\begin{tabular}{lccccc}
\hline Herbicide & Rate $\left(\mathrm{g} \cdot \mathrm{ha}^{-1}\right)$ & Number of applications $^{\mathrm{z}}$ & 4 WAIT $^{\mathrm{y}}$ & 8 WAIT & $12 \mathrm{WAIT}$ \\
\hline Untreated control & - & - & $99 \mathrm{~b}^{\mathrm{x}}$ & $97 \mathrm{c}$ & $98 \mathrm{~d}$ \\
Sulfosulfuron & 13 & 2 & $93 \mathrm{a}$ & $97 \mathrm{c}$ & $95 \mathrm{~d}$ \\
Sulfosulfuron & 27 & 2 & $93 \mathrm{a}$ & $70 \mathrm{~b}$ & $90 \mathrm{~cd}$ \\
Sulfosulfuron & 13 & 3 & $97 \mathrm{~b}$ & $55 \mathrm{~b}$ & $87 \mathrm{~cd}$ \\
Sulfosulfuron & 27 & 3 & $93 \mathrm{a}$ & $14 \mathrm{a}$ & $57 \mathrm{bc}$ \\
Bispyribac-sodium & 37 & 4 & $98 \mathrm{~b}$ & $6 \mathrm{a}$ & $37 \mathrm{ab}$ \\
Bispyribac-sodium & 56 & 4 & $97 \mathrm{~b}$ & $3 \mathrm{a}$ & $12 \mathrm{a}$ \\
Bispyribac-sodium & 74 & 4 & $97 \mathrm{~b}$ & $0 \mathrm{a}$ & $4 \mathrm{a}$ \\
\hline
\end{tabular}

${ }^{\mathrm{z}}$ Applied every 2 weeks.

${ }^{\mathrm{y}} \mathrm{WAIT}=$ weeks after initial treatment.

${ }^{x}$ Means in a column followed by the same letter are not significantly different at $P \leq 0.05$.

Table 5. Percent cover of roughstalk bluegrass as influenced by bispyribac-sodium and sulfosulfuron in Illinois in 2006

\begin{tabular}{lcccc}
\hline Herbicide & Rate $\left(\mathrm{g} \cdot \mathrm{ha}^{-1}\right)$ & Number of applications $^{\mathrm{z}}$ & 4 WAIT $^{\mathrm{y}}$ & $8 \mathrm{WAIT}$ \\
\hline Untreated control & - & - & $99 \mathrm{~b}^{\mathrm{x}}$ & $97 \mathrm{c}$ \\
Sulfosulfuron & 13 & 2 & $93 \mathrm{a}$ & $97 \mathrm{c}$ \\
Sulfosulfuron & 27 & 2 & $93 \mathrm{a}$ & $70 \mathrm{~b}$ \\
Sulfosulfuron & 13 & 3 & $97 \mathrm{~b}$ & $55 \mathrm{~b}$ \\
Sulfosulfuron & 27 & 3 & $93 \mathrm{a}$ & $14 \mathrm{a}$ \\
Bispyribac-sodium & 37 & 4 & $98 \mathrm{~b}$ & $6 \mathrm{a}$ \\
Bispyribac-sodium & 56 & 4 & $97 \mathrm{~b}$ & $3 \mathrm{a}$ \\
Bispyribac-sodium & 74 & 4 & $97 \mathrm{~b}$ & $0 \mathrm{a}$ \\
\hline
\end{tabular}

${ }^{\mathrm{z}}$ Applied every 2 weeks.

${ }^{\mathrm{y}} \mathrm{WAIT}=$ weeks after initial treatment.

${ }^{x}$ Means in a column followed by the same letter are not significantly different at $P \leq 0.05$.

control. Three applications of sulfosulfuron (a.i.) at $27 \mathrm{~g} \cdot \mathrm{ha}^{-1}$ easily outperformed all the other sulfosulfuron treatments, which provided $55 \%$ or greater cover at 8 WAIT. Data were not recorded at 12 WAIT, but we suspect a similar trend would have occurred in Illinois as in Indiana where bispyribac-sodium effects became more pronounced at 12 WAIT.

2006 Wisconsin. Reduction in roughstalk bluegrass cover was evident by 4 WAIT because all treatments decreased cover compared with the untreated control except for 
bispyribac-sodium (a.i.) at $37 \mathrm{~g} \cdot \mathrm{ha}^{-1}$ (Table 6 ). There was little change in percent roughstalk bluegrass cover by 8 WAIT and thus similar results were seen. At 12 WAIT, five of the seven treatments decreased cover to $4 \%$ or less compared with $14 \%$ in the untreated control. The exceptions to this were two applications of sulfosulfuron (a.i.) at $13 \mathrm{~g} \cdot \mathrm{ha}^{-1}$ and four applications of bispyribac-sodium (a.i.) at $37 \mathrm{~g} \cdot \mathrm{ha}^{-1}$. Bispyribacsodium and sulfosulfuron performed similarly at this location.

2006 South Dakota-sun. Sulfosulfuron (a.i.) at $27 \mathrm{~g} \cdot \mathrm{ha}^{-1}$ decreased cover to $8 \%$ and $12 \%$ at 4 WAIT compared with $35 \%$ cover in the untreated control (Table 7). By 8 WAIT, all sulfosulfuron treatments, except for sulfosulfuron (a.i.) applied two times at $13 \mathrm{~g} \cdot \mathrm{ha}^{-1}$, decreased cover to $17 \%$ or less compared with $47 \%$ cover in the untreated control. By 12 WAIT, there were no differences in roughstalk bluegrass cover resulting from the treatments. Overall, sulfosulfuron (a.i.) at $27 \mathrm{~g} \cdot \mathrm{ha}^{-1}$ applied three times provided the best control at this site, unlike Indiana and Illinois where sulfosulfuron was outperformed by bispyribac-sodium.

2006 South Dakota-shade. There were no differences in control of roughstalk bluegrass between treatments at the South Dakota shade site (Table 8). Temperature may have played a role in the lack of control at this site, where cooler temperatures in the shaded environment may have been low enough to decrease the efficacy of both bispyribacsodium and sulfosulfuron. However, temperatures were not monitored at individual sites in South Dakota. Additionally, roughstalk bluegrass is well-adapted and thrives in cool, moist, and shady environments (Beard, 1973). Thus, this weed may be more tolerant of herbicides when it is growing in shade.

Phytotoxicity to creeping bentgrass was observed at every site. Like in 2005, phytotoxicity was noticeable but short-lived and within acceptable levels (data not shown).

Table 6. Percent cover of roughstalk bluegrass as influenced by bispyribac-sodium and sulfosulfuron in Wisconsin in 2006.

\begin{tabular}{lccccc}
\hline Herbicide & Rate $\left(\mathrm{g} \cdot \mathrm{ha}^{-1}\right)$ & Number of applications & 4 WAIT $^{\mathrm{y}}$ & 8 WAIT & 12 WAIT \\
\hline Untreated control & - & - & $16 \mathrm{c}^{\mathrm{x}}$ & $13 \mathrm{c}$ & $14 \mathrm{c}$ \\
Sulfosulfuron & 13 & 2 & $6 \mathrm{ab}$ & $5 \mathrm{ab}$ & $8 \mathrm{bc}$ \\
Sulfosulfuron & 27 & 2 & $3 \mathrm{a}$ & $3 \mathrm{a}$ & $4 \mathrm{ab}$ \\
Sulfosulfuron & 13 & 3 & $3 \mathrm{a}$ & $3 \mathrm{a}$ & $3 \mathrm{ab}$ \\
Sulfosulfuron & 27 & 3 & $3 \mathrm{a}$ & $0 \mathrm{a}$ & $1 \mathrm{ab}$ \\
Bispyribac-sodium & 37 & 4 & $12 \mathrm{bc}$ & $12 \mathrm{bc}$ & $7 \mathrm{abc}$ \\
Bispyribac-sodium & 56 & 4 & $7 \mathrm{ab}$ & $1 \mathrm{a}$ & $1 \mathrm{ab}$ \\
Bispyribac-sodium & 74 & 4 & $6 \mathrm{ab}$ & $2 \mathrm{a}$ & $0 \mathrm{a}$ \\
\hline
\end{tabular}

${ }^{\mathrm{z}}$ Applied every 2 weeks.

${ }^{\mathrm{y}} \mathrm{WAIT}=$ weeks after initial treatment.

${ }^{\mathrm{x}}$ Means in a column followed by the same letter are not significantly different at $P \leq 0.05$.

Table 7. Percent cover of roughstalk bluegrass as influenced by bispyribac-sodium and sulfosulfuron in South Dakota-sun in 2006.

\begin{tabular}{lccccc}
\hline Herbicide & ${\text { Rate }\left(\mathrm{g} \cdot \mathrm{ha}^{-1}\right)}^{\text {Number of applications }}{ }^{\mathrm{z}}$ & ${\text { 4 } \text { WAIT }^{\mathrm{y}}}$ & $8 \mathrm{WAIT}$ & 12 WAIT \\
\hline Untreated control & - & - & $35 \mathrm{c}^{\mathrm{x}}$ & $47 \mathrm{~d}$ & 37 \\
Sulfosulfuron & 13 & 2 & $28 \mathrm{bc}$ & $27 \mathrm{abcd}$ & 30 \\
Sulfosulfuron & 27 & 2 & $8 \mathrm{a}$ & $13 \mathrm{ab}$ & 13 \\
Sulfosulfuron & 13 & 3 & $18 \mathrm{ab}$ & $17 \mathrm{abc}$ & 21 \\
Sulfosulfuron & 27 & 3 & $12 \mathrm{a}$ & $7 \mathrm{a}$ & 5 \\
Bispyribac-sodium & 37 & 4 & $28 \mathrm{bc}$ & $37 \mathrm{~cd}$ & 28 \\
Bispyribac-sodium & 56 & 4 & $32 \mathrm{c}$ & $35 \mathrm{bcd}$ & 30 \\
Bispyribac-sodium & 74 & 4 & $35 \mathrm{c}$ & $28 \mathrm{abcd}$ & 28 \\
\hline
\end{tabular}

${ }^{\mathrm{z}}$ Applied every 2 weeks.

${ }^{\mathrm{y}} \mathrm{WAIT}=$ weeks after initial treatment.

${ }^{\mathrm{x}}$ Means in a column followed by the same letter are not significantly different at $P \leq 0.05$.

Table 8 . Percent cover of roughstalk bluegrass as influenced by bispyribac-sodium and sulfosulfuron in South Dakota-shade in 2006.

\begin{tabular}{lccccc}
\hline Herbicide & Rate $\left(\mathrm{g} \cdot \mathrm{ha}^{-1}\right)$ & Number of applications & 4 $^{\mathrm{z}}$ WIT $^{\mathrm{y}}$ & 8 WAIT & 12 WAIT \\
\hline Untreated control & - & - & 33 & 47 & 38 \\
Sulfosulfuron & 13 & 2 & 40 & 47 & 35 \\
Sulfosulfuron & 27 & 2 & 37 & 40 & 37 \\
Sulfosulfuron & 13 & 3 & 35 & 40 & 45 \\
Sulfosulfuron & 27 & 3 & 28 & 33 & 27 \\
Bispyribac-sodium & 37 & 4 & 33 & 37 & 37 \\
Bispyribac-sodium & 56 & 4 & 32 & 40 & 45 \\
Bispyribac-sodium & 74 & 4 & 38 & 35 & 28 \\
\hline
\end{tabular}

${ }^{\mathrm{z}}$ Applied every 2 weeks.

${ }^{\mathrm{y}} \mathrm{WAIT}=$ weeks after initial treatment.

\section{Conclusions}

Effects of bispyribac-sodium and sulfosulfuron varied among years and locations. Many factors may have played a role in the efficacy of sulfosulfuron and bispyribacsodium. Our preliminary studies have shown that there are differences in cultivar sensitivity to sulfosulfuron (Morton and Reicher, 2007). The cultivar of rough bluegrass used in Indiana in both years was 'Laser', which our work shows is less sensitive to sulfosulfuron than other cultivars (Morton and Reicher, 2007). This could explain the poor control from sulfosulfuron in Indiana, but we are unsure if it played a role at other sites as they were preexisting contaminations. Temperature may also have affected efficacy of sulfosulfuron and bispyribac-sodium in this study. Bispyribac-sodium works best at warmer temperatures $\left(\approx 24\right.$ to $30{ }^{\circ} \mathrm{C}$ versus $\approx 14$ to $21^{\circ} \mathrm{C}$ ) (Lycan and Hart, 2006). Early research has also shown that roughstalk bluegrass sensitivity to sulfosulfuron increases with temperature (McCullough and Hart, 2006b). This could help explain poor control from sulfosulfuron in the May 2005 application in Indiana and poor control from both herbicides in the South Dakota shade site in 2006.

Recommending a single best strategy for roughstalk bluegrass control using these herbicides is difficult because of the variability. More precise recommendations will result with our future research as well as experience by practitioners. That being said, our current recommendations include starting initial applications in June after daytime temperatures exceed at least $21^{\circ} \mathrm{C}$. Furthermore, we suggest three applications of sulfosulfuron (a.i.) applied at $27 \mathrm{~g} \cdot \mathrm{ha}^{-1}$ at 2week intervals or four applications of bispyribac-sodium (a.i.) applied at 56 or 74 $\mathrm{g} \cdot \mathrm{ha}^{-1}$ at 2-week intervals for most rapid and effective roughstalk bluegrass control. In fairways with significant roughstalk bluegrass populations, a slower approach may be desired to gradually remove roughstalk bluegrass. In this case, multiple applications of sulfosulfuron at lower rates could potentially reduce roughstalk bluegrass over multiple years.

\section{Literature Cited}

Anonymous. 2004. Velocity product label. Valent U.S.A. Corp., Walnut Creek, CA.

Anonymous. 2005. Certainty product label. Monsanto Company, St. Louis, MO.

Beard, J.B. 1973. Turfgrass science and culture. Prentice Hall \& Co, Englewood Cliffs, NJ.

Christians, N. 2004. Fundamentals of turfgrass management. John Wiley and Sons, Inc., Hoboken, NJ.

Lycan, D.W. and S.E. Hart. 2004. Relative tolerance of four cool-season turfgrass species to sulfosulfuron. Weed Technology 18:977981.

Lycan, D.W. and S.E. Hart. 2006. Seasonal effects on annual bluegrass (Poa annua) control in creeping bentgrass with bispyribac-sodium. Weed Technology 20:722-727. 
McCullough, P.E. and S.E. Hart. 2006a. Temperature influences creeping bentgrass (Agrostis stonlonifera) and annual bluegrass (Poa annua) response to bispyribac-sodium. Weed Technology 20:728-732.

McCullough, P.E. and S.E. Hart. 2006b. Temperature influences efficacy of bispyribac-sodium, primisulfuron, and sulfosulfuron. Proc. 15th Annual Rutgers Turfgrass Symposium. p. 40 (abstr.).
Morton, D.E. and Z.J. Reicher. 2007. Effect of certainty and velocity on cultivars of $\mathrm{Poa}$ trivialis. 2006 Purdue turfgrass research summary 6 Sept. 2007. <http://www.agry.purdue. edu/turf/report/2006/18.pdf $>$.

Olson, B.L.S., K. Al-Khatib, P. Stahlman, and P.J. Isakson. 2000. Efficacy and metabolism of MON 37500 in Triticum aestivum and weedy grass species as affected by tem- perature and soil moisture. Weed Sci. 48:541-548.

Shimizu, T., I. Nakayama, K. Nagayama, T. Miyazawa, and Y. Nezu. 2002. Acetolactate synthase inhibitors, pp. 1-41. In: P. Boger, K. Wakabayashi, and K. Hirai (eds.). Herbicide classes in development: Mode of action, targets, genetic engineering, chemistry. SpringerVerlag, New York. 